\title{
Effect of Preheating Temperature on the Mechanical and Fracture Properties of Welded Pearlitic Rail Steels
}

\author{
Heshmat A. Aglan ${ }^{1 *}$, Sudan Ahmed ${ }^{1}$, Kaushal R. Prayakarao ${ }^{1}$, Mahmood Fateh $^{2}$ \\ ${ }^{1}$ Mechanical Engineering Department, Tuskegee University, Tuskegee, USA \\ ${ }^{2}$ Federal Railroad Administration, Washington DC, USA \\ Email:*aglanh@mytu.tuskegee.edu
}

Received June 11, 2013; revised July 11, 2013; accepted July 18, 2013

Copyright (C) 2013 Heshmat A. Aglan et al. This is an open access article distributed under the Creative Commons Attribution License, which permits unrestricted use, distribution, and reproduction in any medium, provided the original work is properly cited.

\begin{abstract}
The effect of preheating temperature on the mechanical and fracture behavior, hardness, and the microstructure of slot welded pearlitic rail steel were studied. Railhead sections with slots were preheated to $200^{\circ} \mathrm{C}, 300^{\circ} \mathrm{C}, 350^{\circ} \mathrm{C}$ and $400^{\circ} \mathrm{C}$ before gas metal arc filling to simulate defects repair. Another sample, welded at room temperature (RT) with no preheat, was studied in comparison. The parent rail steel has ultimate strength, yield strength and strain to failure of 1146 MPa, $717 \mathrm{MPa}$ and 9.3\%, respectively. Optimum values of these properties for the welded rail steels were found to be $1023 \mathrm{MPa}, 655 \mathrm{MPa}$ and $4.7 \%$, respectively, for the $200^{\circ} \mathrm{C}$ preheat temperature. On this basis, the optimum weld efficiency was found to be $89.2 \%$. The average apparent fracture toughness $K_{I}$ for the parent rail was $127 \mathrm{MPa} . \mathrm{m}^{0.5}$, while that for the optimum welded joint $\left(200^{\circ} \mathrm{C}\right.$ preheat) was $116.5 \mathrm{MPa} \cdot \mathrm{m}^{0.5}$. In addition, the average hardness values of the weld, fusion zone, and heat affected zone (HAZ) were 313.5, 332 and $313.6 \mathrm{HB}$, respectively, while that for parent rail steel was about $360 \mathrm{HB}$. Dominance of bainite and acicular ferrite phase in the weld microstructure was observed at $200^{\circ} \mathrm{C}$ preheat.
\end{abstract}

Keywords: Preheat Temperature; Welded Rail Steels; Weld Microstructure; Welding Efficiency; Fracture Toughness

\section{Introduction}

Preheating can be defined as heating the base metal(s) to a certain temperature before welding. Preheating serves 4 major purposes [1,2]: a) to decrease cooling rate, which produces ductile microstructure that increases resistance to cracking and helps in diffusion of hydrogen; b) to reduce shrinkage stress between the weld zone and base metal; c) to prevent chilling effect ("cold start") and ensure proper fusion; and d) to eliminate moisture from the sample surface. However, excessive preheating is expensive and yields defects such as thermal distortion in welded component [3]. On the other hand, inadequate preheating results in different types of cracking, insufficient fusion, and penetration [4]. Carbon equivalent (CE) is used as a tool for approximating proper preheats [2,5]. Beside CE, optimum preheating temperature also depends on section thickness, restraint, ambient temperature, filler metal hydrogen content, and previous cracking problems [1].

Microstructure of C-Mn steel weld generally consists

${ }^{*}$ Corresponding author. of allotriomorphic ferrite, acicular ferrite, widmanstatten ferrite, and microphases [6-9]. Different alloying elements have been added to improve strength and toughness of these C-Mn weld joints. Ni and Mn are used to increase harden ability and promote acicular ferrite by suppressing allotriomorphic ferrite formation, whereas, $\mathrm{Cr}$ and Mo assist in promoting bainite formation instead of acicular ferrite. Typical weld microstructure of high strength filler material alloyed with metals such as, $\mathrm{Ni}$, $\mathrm{Mn}, \mathrm{Cr}$ and Mo consists of a mixture of acicular ferrite, bainite, and low carbon martensite. Relative proportion of these phases mainly depends on chemical composition and thermal cycle during welding $[8,9]$.

Along with other factors, cooling rate plays an important role in determining final weld microstructure. Shia and Han reported that the volume fraction of martensite decreases with decreasing cooling rate [10]. However, cooling rate decreases with increasing preheat temperature and heat input. The relation between cooling rate with preheat temperature and heat input is

$$
R \propto 1 / T H
$$

where $R$ is cooling rate, $T$ is preheating temperature and 
$H$ is heat input [11].

The width of the fusion zone depends on the time the temperature of this zone remains above melting point of the material. A higher preheat temperature increases the time span and thus results in an increased width of the fusion zone [12].

Preheat temperature has a strong influence on the phases that form in the weld microstructure. Recent investigation on laser hybrid welded $10 \mathrm{Ni} 3 \mathrm{CrMoV}$ steel showed that at a lower preheat $\left(90^{\circ} \mathrm{C}\right)$, lath martensite and upper bainite that are formed do not have enough time for self tempering. At a higher preheat $\left(120^{\circ} \mathrm{C}\right)$, with enough self-tempering time, acicular ferrite is formed along with lath martensite. Hence, better toughness and lower cracking results with this preheat temperature. However, at a still higher preheat temperature $\left(150^{\circ} \mathrm{C}\right)$ it was found that the toughness was reduced due to granular bainite and martensitic/austenitic (M/A) constitutes in the microstructure [13].

When shrinkage of solidifying weld deposit is inhibited by surrounding parent metal, the weld zone remains in a residual tensile stress [14]. Weld residual stress was found to decrease with increasing preheating temperature $[15,16]$.

In a multipass welding, subsequent beads are deposited one upon another to fill the gap. Hence all the layers, except the topmost layer, experience additional thermal cycles due to heat from layers above. These thermal cycles could be high enough to reaustenize the weld beads. Portions of weld bed where temperature is not high enough to revert back to austenite also exhibit a tempered microstructure [17].

Hardness of the weld zone and HAZ depends on heat input, cooling rate, and peak temperature reached during welding [18]. Though hardness testing provides a rough assessment of weld, other mechanical evaluations such as tensile, fracture toughness, and fatigue should be performed to obtain a comprehensive idea about weld quality [19]. Tensile tests are performed on a welded joint to know the strength of the joint in comparison to the parent steel. The ratio of ultimate tensile strength of the welded sample and the parent sample is known as weld efficiency [20]. Fracture toughness reveals the resistance of the material against crack propagation. For carbon steel, fracture toughness generally increases with decreasing coarseness of the grain [21].

In the present work, slot was milled on rail head and was filled with multipass gas metal arc welding (GMAW) to simulate in service repair. Five different preheating temperatures were used. Mechanical testing, metallographic analysis, and fracture behavior analysis were carried out on the welded samples. The optimum preheat temperature has been identified in view of the welding efficiency and the fracture resistance of the welded rail head.

\section{Materials and Experimental}

The materials used in the present study were supplied by the Transportation Technology Center, Inc. (TTCI). ESAB-140 (specified by the military standard MIL 140S1) was used as a filler material (see Table $\mathbf{1}$ for chemical composition) and is manufactured by ESAB Welding and Cutting.

A slot of $25.4 \mathrm{~mm}$ wide and $19.05 \mathrm{~mm}$ depth was made at the center of each section of rail sample to simulate removal of defects from a rail head. Electric strip heaters (250 watt heat transfer capacity) were clamped on both sides of the web of a rail section to preheat the slot. Ceramic fiber was used to wrap the sections in order to minimize the heat loss. Four different preheat temperatures $\left(200^{\circ} \mathrm{C}, 300^{\circ} \mathrm{C}, 350^{\circ} \mathrm{C}\right.$ and $\left.400^{\circ} \mathrm{C}\right)$ along with a room temperature (RT) sample with no preheat were chosen for the current study. After the desired preheat temperature was attained, multipass GMAW was performed to fill the slots (Figure 1(a)). The voltage applied was 23 volt, wire feed speed rate was 250 IPM, and the heat input was approximately $1.18 \mathrm{~kJ} / \mathrm{mm}$. The interpass temperature used was a $50^{\circ} \mathrm{C}$ higher than the selected preheat temperature. Approximately 28 passes were made to completely fill the slot. The rail section was then allowed to cool after the welding and any excessive material was ground off from the surface. The welded rail head was then sliced into thin sections of dimensions $136 \mathrm{~mm}$ long and $12.7 \mathrm{~mm}$ wide and $2.5 \mathrm{~mm}$ thick. For the fracture test, a $60^{\circ}$ notch was introduced at one edge to the center of the weld with a $5 \mathrm{~mm}$ depth for the notch, and a depth to width ratio $(\mathrm{a} / \mathrm{W})$ of about 0.4 . A minimum gage length of $72 \mathrm{~mm}$ was set for both notched and unnotched static tensile testing (Figure 1(b)).

Hardness tests were performed on the samples at different locations across the weld using a Clark CLC-200R hardness tester. Microstructural analyses of the parent, HAZ, and weld regions were conducted using an Olympus GX51 metallurgical optical microscope. A servo hydraulic material testing system (MTS 810) with a $100 \mathrm{kN}$ load cell connected with Test star II software was used for static tensile tests, both on notched and un-notched samples.

\section{Results and Discussion}

\subsection{Hardness Distribution of Welded Pearlitic Rail Steel}

Hardness of welded samples was measured at different locations from the weld center. A carbide diamond indenter tip was used with a $150 \mathrm{kgf}$ load for the hardness measurement. Figure 2 shows the hardness profiles of the welded samples with different preheat temperature. 
Table 1. Chemical composition of rail steel and filler material by weight percent.

\begin{tabular}{ccccccccccc}
\hline Element & $\mathrm{C}$ & $\mathrm{Mn}$ & $\mathrm{Si}$ & $\mathrm{Cr}$ & $\mathrm{Mo}$ & $\mathrm{Ti}$ & $\mathrm{Cu}$ & $\mathrm{P}$ & $\mathrm{Ni}$ & $\mathrm{Al}$ \\
\hline Parent & 0.92 & 0.85 & 0.405 & $\sim 0.22$ & - & 0.1 & $\sim 0.3$ & $\sim 0.015$ & - & - \\
ESAB-140 & 0.08 & 1.70 & 0.40 & 0.90 & 0.60 & - & - & 0.005 & 2.4 & - \\
\hline
\end{tabular}

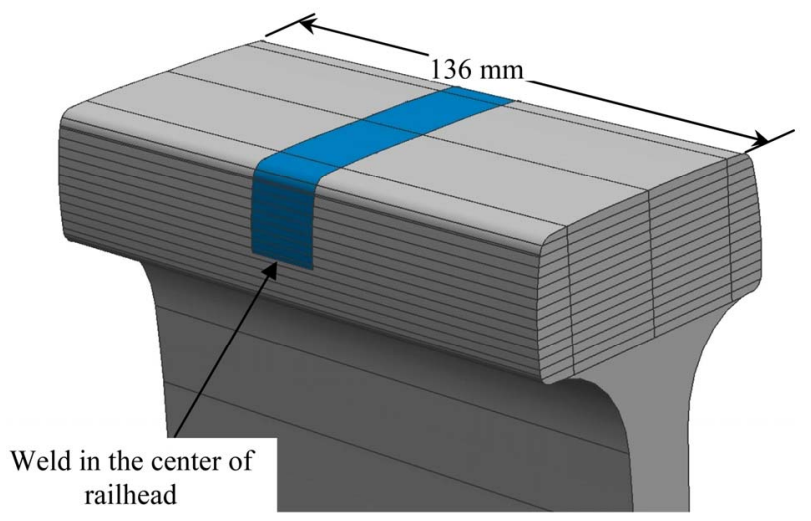

(a)

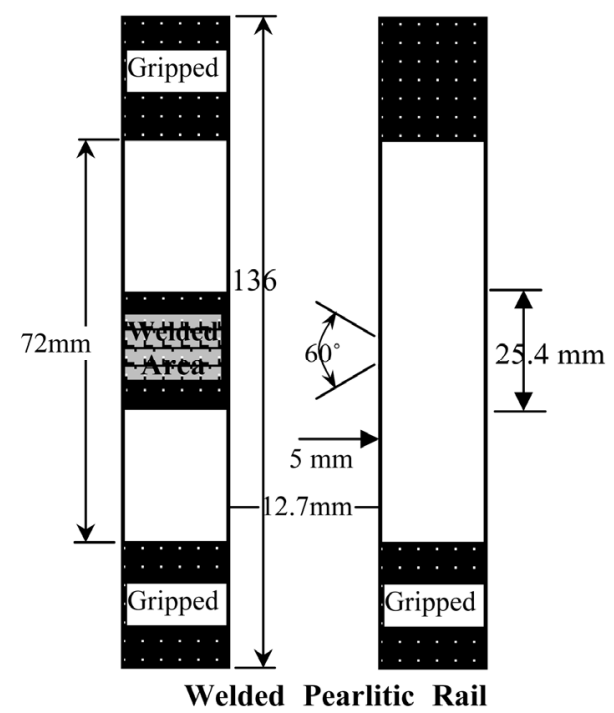

(b)

Figure 1. (a) schematic diagram of a railhead section showing the slot weld and (b) geometry of notched and unnotched specimens for tensile and fracture tests.

All of the preheated samples displayed similar hardness distribution curves-a lower value at the weld, an increase near the fusion line and then a decrease again in the HAZ. The average hardness of the parent rail steel was found to be $360 \mathrm{HB}$. Maximum and minimum average weld hardness was obtained for the $350^{\circ} \mathrm{C}$ and $400^{\circ} \mathrm{C}$ preheated samples and was $336.7 \mathrm{HB}$ and $295.3 \mathrm{HB}$, respectively. Among these preheats, the average hardness of HAZ was found to decrease with increasing preheat temperature. Maximum HAZ hardness was $313.6 \mathrm{HB}$, obtained at $200^{\circ} \mathrm{C}$ preheat, and the minimum was $281.1 \mathrm{HB}$, obtained at $400^{\circ} \mathrm{C}$ preheat.
Hardness of weld zone strongly depends on the filler material and the resulting thermal cycles produced during application of successive layers in multipass welding.

The variation in the hardness values for parent, weld and HAZ can be explained from their chemical compositions. The filler material had a lower carbon percentage when compared to the parent. Carbon percent is a standard measure of the hardness as carbon is directly proportional to the hardness of the material. Higher hardness near the fusion zone can be attributed to the formation of a harder phase due to the combined effects of both the carbon diffusion from the parent material and the rapid cooling rate of the weld metal from the liquid state [22]. Generally, the HAZ undergoes heat treatment at the time of welding that causes nucleation and growth of austenite resulting in reduction of work hardening and dislocation number [23]. As a result, the hardness of the HAZ is reduced. A similar result was found in present study. Additionally, it is evident (Figure 2) that as the preheat temperature increases, the HAZ hardness decreases. A slower cooling rate at a higher preheat temperature might be a reason for this trend. Further studies will be done in an attempt to increase weld's hardness.

A slight difference in hardness distribution was obtained for the rail sample welded without any preheat (RT). The HAZ hardness for this sample was very high, even higher than the parent. This contradicts the explanation presented in the previous paragraph. When welding was performed on no preheat (RT) sample, the cooling rate was faster. Besides, the carbon content of the parent is much higher ( $0.9 \mathrm{wt} \% \mathrm{C})$. These two factors might contribute to a harder phase (like martensite) in the HAZ.

\subsection{Microstructure of Welded Rail}

The microstructure of the welded rail steel was investigated at different locations of the weldment. Figure 3 shows a schematic representation of the welded sample indicating the different zones.

The microstructures of the weld zones for all the welded samples with different preheat temperatures were similar and mostly evident of a mixture of acicular ferrite and bainite. However, a different weld microstructure, which is a mixture of martensite and bainite, was observed for the samples welded with no preheat (RT). Figures 4 and 5 represent micrographs taken at the fusion and weld zones for both room temperature and $200^{\circ} \mathrm{C}$ preheated samples. 


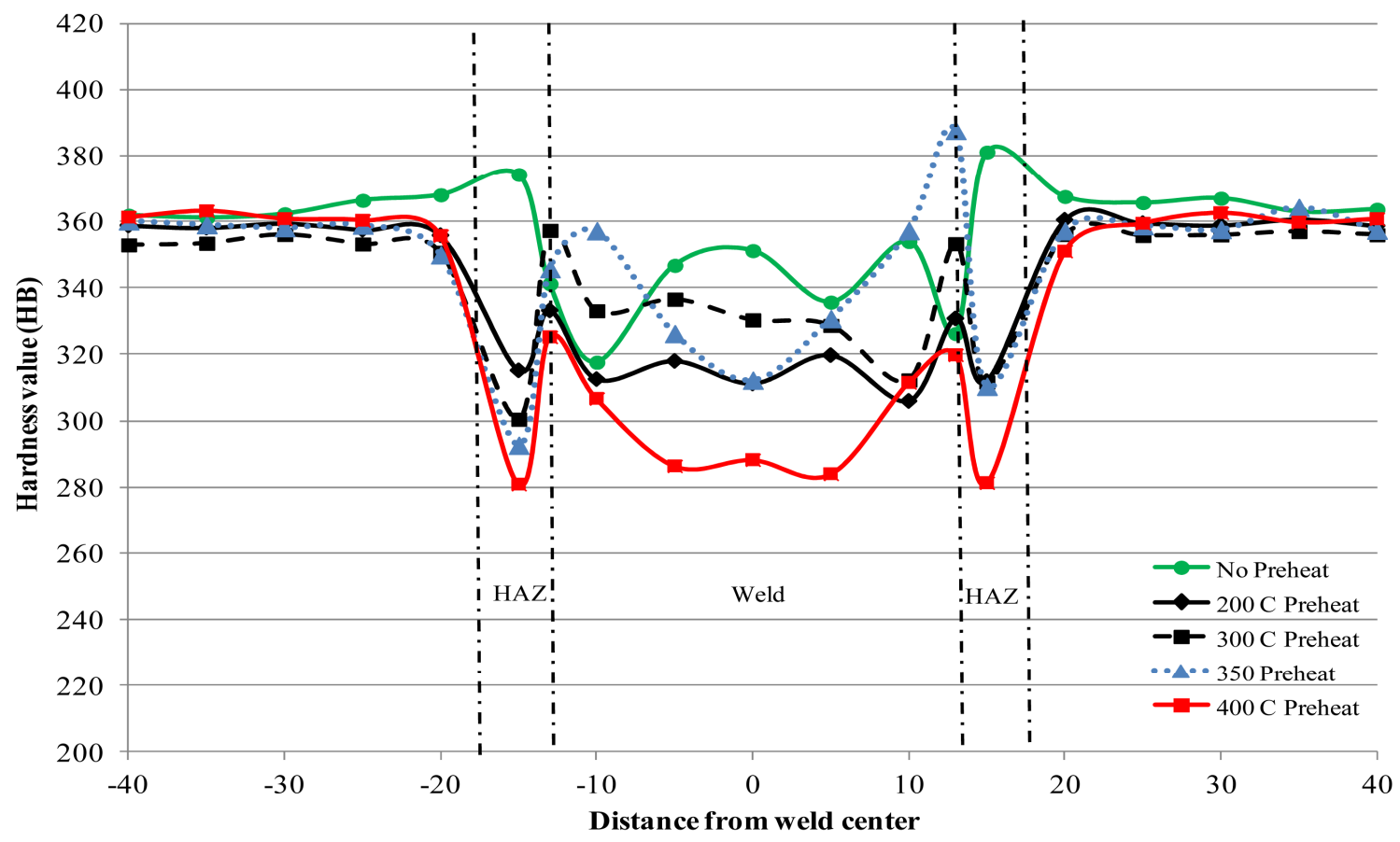

Figure 2. Hardness distribution of rail steel welded with different preheat temperatures.

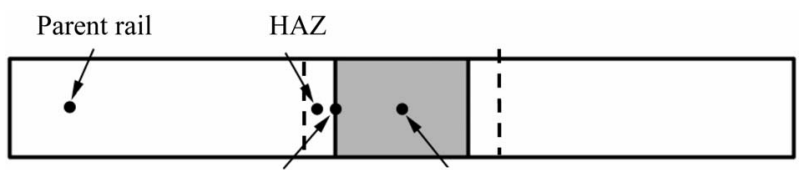

(a)

Figure 3. A schematic of the test specimen indicating the locations of the micrographs taken for microstructural analysis. (a) Fusion; (b) Weld.

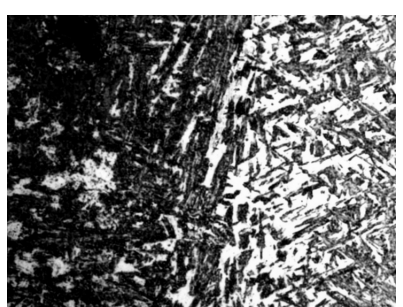

(a)

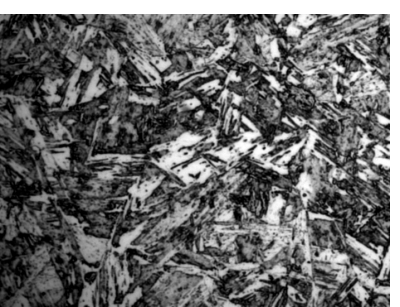

(b)

Figure 4. Micrograph of welded sample with no preheat, (a) near fusion (b) weld.

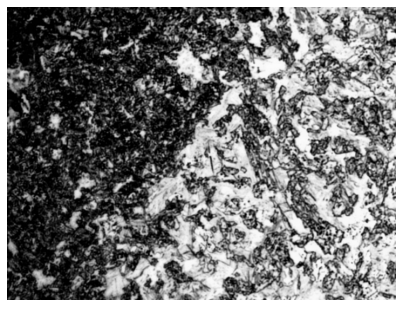

(a)

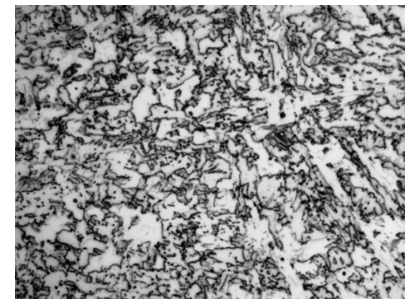

(b)

Figure 5. Micrograph of welded sample at $200^{\circ} \mathrm{C}$ preheat, (a) near fusion (b) weld.

In the case of dissimilar filler welding, a small portion of the base metal melts and mixes with the filler material to form a weldment. The percentage of the weld that comes from base metal during welding is known as the dilution percentage [24]. In the present work, since there is a large difference in the chemistries of the parent rail and the filler material (especially wt\% C), the weld composition might vary depending on the percentage of dilution. Considering the base metal dilution, the carbon percentage of the weld for different preheating conditions was determined by weld cross-section and the composition calculation [25] (Table 2). It is clear that the wt\% C for the weld increases with increasing preheat temperature. Another important factor of preheating is that it decreases the cooling rate. A higher the preheat temperature lresults in aower the cooling rate.

It is well established that an increasing carbon percentage in steel will shift the continuous cooling transformation (CCT) diagram to the right. Since an increaseing preheat temperature will increase the $w \mathrm{t} \% \mathrm{C}$ in the weld, the CCT diagram will shift to right. In contrary, a higher preheat temperature will reduce the cooling rate and will also shift the cooling curve to the right. Due to the above mentioned combined effects, the cooling curves for different preheat temperatures most likely cut the CCT diagram in the same region. Hence, we can expect a similar weld microstructure for different preheat temperatures. However, for s welded sample with no preheat (RT), the cooling rate will be much higher when compared to other preheated samples, as well as to the parent rail, and will act as a heat sink. It is believed that 
due to this very high cooling rate, martensite and bainite were formed in their microstructures.

\subsection{Mechanical and Fracture Performance}

Tensile and fracture test data for parent and welded specimens are presented in Table 3. The ultimate tensile strength (UTS) and strain of the parent rail was found to be $1146 \mathrm{MPa}$ and $9.3 \%$, respectively. The ultimate tensile strengths of all the welded specimens with different preheats were found to be similar. The maximum tensile strength (1023 MPa), which is about $11 \%$ less than that of the parent steel, was obtained at the $200^{\circ} \mathrm{C}$ preheat temperature. The maximum strain $(6 \%)$ was obtained at the $300^{\circ} \mathrm{C}$ preheat. This is a $35 \%$ decrease in strain when compared to the parent. The maximum yield strength (718 MPa) was obtained for the $400^{\circ} \mathrm{C}$ preheated samples. This is similar to that of the parent steel $(717 \mathrm{MPa})$. Yield strengths of other preheated samples $\left(200^{\circ} \mathrm{C}\right.$, $300^{\circ} \mathrm{C}$, and $350^{\circ} \mathrm{C}$ ) were about $8 \%$ less than the parent. Except for $350^{\circ} \mathrm{C}$ preheat temperature, all the other welded samples showed a similar modulus of elasticity as the parent. The modulus of elasticity for the welded rail with a $350^{\circ} \mathrm{C}$ preheat temperature was $951.7 \mathrm{GPa}$, which is $3.6 \%$ higher than that of the parent.

The minimum strength, as well as strain, was $836 \mathrm{MPa}$ and $3.4 \%$, obtained for samples welded with no preheat (RT). During the welding processes, the liquid weld deposit tries to contract as it solidifies. Additionally, the unmelted parent around the weld prevents the contraction of the weld. As a result, the weld zone remains under residual tensile stress. It is established that preheating helps reduce the weld residual stresses significantly $[15,16]$. It is considered that the presence of a higher

Table 2. Carbon content of weld for different preheat temperatures.

\begin{tabular}{cccccc}
\hline Preheat Temp. & None & $200^{\circ} \mathrm{C}$ & $300^{\circ} \mathrm{C}$ & $350^{\circ} \mathrm{C}$ & $400^{\circ} \mathrm{C}$ \\
\hline Wt\% C & 0.13 & 0.15 & 0.17 & 0.19 & 0.2 \\
\hline
\end{tabular}

amount of residual stress, in the case of room temperature weld samples, might be a reason for the lower tensile strength.

Weld efficiency is defined as the ratio of ultimate tensile strength of weld to parent. This is a powerful tool to assess a weld's performance. Weld efficiency of samples welded at different preheat temperatures is shown in Figure 6. The slight deviations in the error bars (Figure 6) indicate the consistency of the values obtained for any individual preheat temperature.

It is evident that the weld efficiency is lower for the samples with no preheat (RT). The weld efficiency increased significantly after introducing preheat and was about $90 \%$. Variation of preheat temperature, in the range of $200^{\circ} \mathrm{C}$ to $400^{\circ} \mathrm{C}$, does not have any significant effect on weld efficiency.

Residual strengths were determined for both parent and welded rail steels after testing samples with simulated defects. A $5 \mathrm{~mm}$ deep notch was introduced with a crack length to width (a/W) ratio of 0.4 . The apparent fracture toughness $\left(\mathrm{K}_{\mathrm{I}}\right)$ was calculated using a formula mentioned in JSMS handbook [26]. Variation in the fracture toughness ratio of parent to weld with respect to preheat temperature is presented in Figure 6. It can be seen that the toughness ratio does not vary significantly for different preheat temperatures and is about 0.9. The higher value of residual strength (Table 3) for the sample with no preheat (RT) is contradictory to the lowest value of tensile strength (as discussed in earlier section). The presence of a high weld residual stress (due to contraction of the weld) was considered to initiate a crack (during tensile test) at a lower tensile stress. This results in a lower tensile strength of this weld. On the other hand, during the fracture toughness evaluation, a crack was introduced with a notch in the weld. Hence the presence of weld residual stress might not play a significant role in the crack propagation.

\section{Conclusions}

Preheating has a significant effect on the properties of a

Table 3. Summary of all tensile and fracture test data.

\begin{tabular}{cccccccccc}
\hline \multirow{2}{*}{$\begin{array}{c}\text { Preheat } \\
\text { Temp. }{ }^{\circ} \mathbf{C}\end{array}$} & $\begin{array}{c}\text { Slot } \\
\text { Temp. }{ }^{\circ} \mathbf{C}\end{array}$ & \multicolumn{3}{c}{ Tensile Test } & \multicolumn{3}{c}{ Fracture Test } \\
\cline { 3 - 10 } & & UTS (Mpa) & Y.S. (Mpa) & Strain (\%) & Mod. (Gpa) & Eff. (\%) & Residual Strength (Mpa) & Strain (\%) & \multicolumn{1}{c}{$\mathbf{K}_{\mathrm{I}}$} \\
\hline Parent & & $1146 \pm 18$ & $717 \pm 10$ & $9.3 \pm 0.7$ & $918 \pm 8$ & & $481 \pm 17$ & $0.6 \pm 0$ & $127.4 \pm 3.6$ \\
None & 25 & $836 \pm 19$ & $738 \pm 14$ & $3.4 \pm 0.5$ & $905 \pm 15$ & $72.9 \pm 1.6$ & $472 \pm 5$ & $2.63 \pm 0.2$ & $122.4 \pm 1.7$ \\
200 & 157 & $1023 \pm 7$ & $655 \pm 5$ & $4.7 \pm 0.7$ & $917 \pm 40$ & $89.2 \pm 0.6$ & $437 \pm 10$ & $1.8 \pm 0.1$ & $116.5 \pm 2.9$ \\
300 & 232 & $1015 \pm 22$ & $658 \pm 8$ & $6.0 \pm 0.9$ & $908 \pm 38$ & $88.6 \pm 2.0$ & $436 \pm 4$ & $2.1 \pm 0.1$ & $112.1 \pm 1.0$ \\
350 & 263 & $996 \pm 17$ & $652 \pm 3$ & $4.7 \pm 0.5$ & $952 \pm 8$ & $86.9 \pm 1.5$ & $436 \pm 4$ & $1.7 \pm 0.2$ & $116.2 \pm 1.2$ \\
400 & 288 & $997 \pm 11$ & $718 \pm 8$ & $4.1 \pm 0.2$ & $921 \pm 13$ & $87.0 \pm 0.9$ & $427 \pm 3$ & $1.9 \pm 0.1$ & $112.1 \pm 0.9$ \\
\hline
\end{tabular}




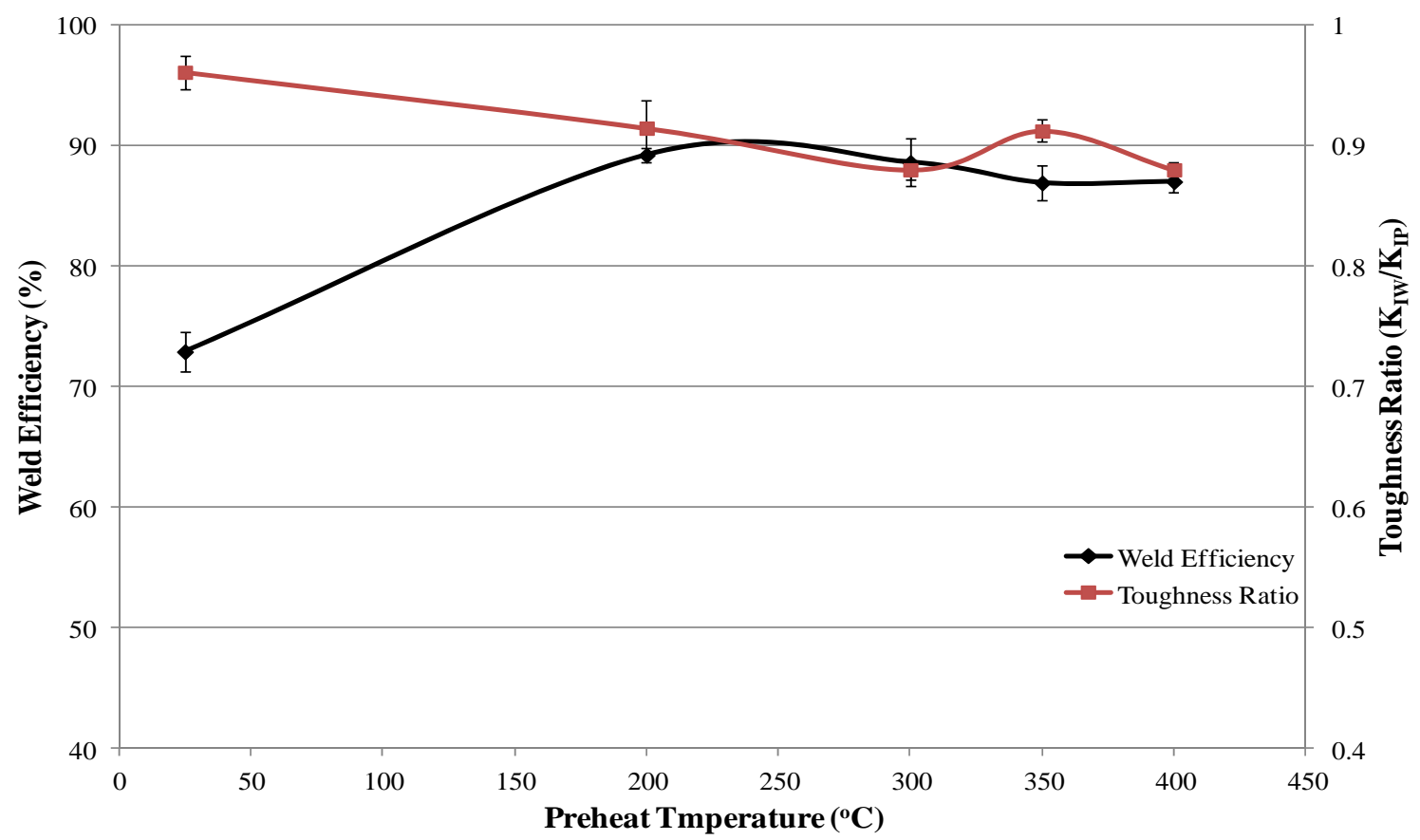

Figure 6. Weld efficiency and fracture toughness ratio plotted against different preheat temperatures.

slot welded pearlitic rail steel. Mechanical properties were poor when welding was performed at room temperature with no preheat. In the range of preheat temperature $\left(200^{\circ} \mathrm{C}\right.$ to $\left.400^{\circ} \mathrm{C}\right)$ used in this work, no significant change in microstructure, mechanical and fracture properties was observed depending on preheat temperature. This temperature was measured on the weld surface below the slots.

The microstructure of welded rails with different preheat temperatures was mostly a mixture of acicular ferrite and bainite. However, martensite and bainite were identified as main constituents for the rail welded with no preheat (RT). The presence of a significant amount of martensite in the weld microstructure and weld residual stress might be the reasons for lower mechanical properties of the welded rail without any preheat.

Higher carbon content in the weld and reduced cooling rate at the higher preheat temperature might be responsible for producing similar microstructure and similar mechanical and fracture properties at different preheat temperatures.

Since a higher preheat temperature involves extra energy to achieve, $200^{\circ} \mathrm{C}$ can be recommended for preheating slot welding of pearlitic rail steel.

\section{Acknowledgements}

This work was sponsored by the Federal Railroad Administration (FRA). The authors would also like to acknowledge Dr. Ronald J. O’Malley of Nucor Steel, Decatur, for his valuable comments and feedback.

\section{REFERENCES}

[1] R. S. Funderburk, “Talking Your Weld's Temperature,” Proceedings on North American Steel Construction Conference, Las Vegas, February 2000.

[2] BOC Library, AU: IPRM: 2007: Section 8: Consumable, pp. 326-329.

http://www.bocworldofwelding.com.au/media/pdf/file/lib rary/WOWLibrary-Preheating\%20of\%20materials-Consu mables.pdf

[3] T. Kasuya and N. Yuriok, "Determination of Necessary Preheat Temperature to Avoid Cold Cracking under Varying Ambient Temperature,” ISIJ International, Vol. 35, No. 10, 1995, pp. 1183-1189. http://dx.doi.org/10.2355/isijinternational.35.1183

[4] L. Baughurst and G. Voznaks: "Welding Defects, Causes and Correction,” Australian Bulk Handling Review, 2009. http://www.bulkhandling.com.au/pdfs/26-28.pdf

[5] R. W. Hinton and R. K. Wiswesser: "Estimating Welding Preheat Requirements for Unknown Grades of Carbon and Low Alloy Steels,” Welding Journal, Vol. 87, 2008, pp. 273-278.

[6] S. Kou, "Welding Metallurgy,” 2nd Edition, John Wiley \& Sons, Inc., Hoboken, 2003, pp. 232-239.

[7] H. K. D. H. Bhadeshia, "Reliability of Weld Microstructure and Property Calculations," Welding Journal, Vol. 8, No. 9, 2004, pp. 237-243.

[8] W. W. Bose-Filho, A. L. M. Carvalho and M. Strangwood, "Effects of Alloying Elements on the Microstructure and Inclusion Formation in HSLA Multipass Welds," Materials Characterization., Vol. 58, No. 1, 2007, pp. 29-39. http://dx.doi.org/10.1016/j.matchar.2006.03.004

[9] H. K. D. H. Bhadeshia, "The Microstructure of Sub- 
merged Arc-Weld Deposits for High-Strength Steels,” Journal of Materials Science, Vol. 24, No. 9, 1989, pp. 3180-3188. http://dx.doi.org/10.1007/BF01139039

[10] Y. Shia and Z. Han, "Effect of Weld Thermal Cycle on Microstructure and Fracture Toughness of Simulated Heat-Affected Zone for a 822 MPa Grade High Strength Low Alloy Steel," Journal of Materials Processing Technology, Vol. 207, No. 1-3, 2008, pp. 30-39. http://dx.doi.org/10.1016/j.jmatprotec.2007.12.049

[11] R. S. Funderburk, “A Look at Heat Input,” Welding Innovation, Vol. 16, No. 1, 1999, pp. 8-11.

[12] E. M. El-Banna: "Effect of Preheat on Welding of Ductile Cast Iron,” Materials Letters, Vol. 41, No. 1, 1999, pp. 20-26. http://dx.doi.org/10.1016/S0167-577X(99)00098-1

[13] L. H. Hu, J. Huang, Z. G. Li and Y. X. Wu, "Effects of Preheating Temperature on Cold Cracks, Microstructures and Properties of High Power Laser Hybrid Welded 10Ni3CrMoV Steel,” Materials \& Design, Vol. 32, 2011, pp. 1931-1939.

[14] D. K. Miller, "The Challenge of Welding Jumbo Shapes," Welding Innovation, Vol. 10, No. 1, 1993, pp. 3-5.

[15] T. Teng and C. Lin, "Effect of Welding Conditions on Residual Stresses Due to Butt Welds," International Journal of Pressure Vessels and Piping, Vol. 75, No. 12, 1998, pp. 857-864. http://dx.doi.org/10.1016/S0308-0161(98)00084-2

[16] A. Fallahi, K. Jafarpur and M. R. Nami, "Analysis of Welding Conditions Based on Induced Thermal Irreversibilities in Welded Structures: Cases of Welding Sequences and Preheating Treatment," Scientia Iranica, Vol. 18, No. 3, 2011, pp. 398-406.

[17] R. C. Reed and H. K. D. H. Bhadeshia, "A Simple Model for Multipass Steel Welds," Acta Metallurgica et Materialia, Vol. 42, No. 11, 1994, pp. 3663-3678. http://dx.doi.org/10.1016/0956-7151(94)90432-4

[18] E. M. El-Banna, M. S. Nageda and M. M. A. El-Saadat,
"Study of Restoration by Welding of Pearlitic Ductile Cast Iron,” Materials Letters, Vol. 42, No. 5, 2000, pp. 311-320. http://dx.doi.org/10.1016/S0167-577X(99)00204-9

[19] M. Saarna and A. Laansoo, "Rail and Rail Weld Testing," Proceedings of 4th International DAAAM Conference on Industrial Engineering-Innovation as Competitive Edge for SME, Tallinn, April 2004, pp. 217-219.

[20] T. W. Orange: "Evaluation of Special 301-Type Stainless Steel for Improved Low-Temperature Notch Toughness of Cryoformed Pressure Vessels," Report TND-3445, NASA, Washington DC, 1966.

[21] J. J. Lewandowski and A. W. Thompson, "Microstructural Effects on the Cleavage Fracture Stress of Fully Pearlitic Eutectoid Steel," Metallurgical and Materials Transactions A, Vol. 17, No. 10, 1986, pp. 1769-1786. http://dx.doi.org/10.1007/BF02817275

[22] B. Gulenc and N. Kahraman: "Wear Behaviour of Bulldozer Rollers Welded Using a Submerged Arc Welding Process,” Materials \& Design., Vol. 24, No. 7, 2003, pp. 537-542. http://dx.doi.org/10.1016/S0261-3069(03)00082-7

[23] E. Gharibshahiyan, A. H. Raouf, N.Parvin and M. Rahimian, "The Effect of Microstructure on Hardness and Toughness of Low Carbon Welded Steel Using Inert Gas Welding," Materials \& Design, Vol. 32, No. 4, 2011, pp. 2042-2048. http://dx.doi.org/10.1016/j.matdes.2010.11.056

[24] Carbon Steel to Austenitic Steel. http://www.gowelding.com/met/diss.html

[25] R. E. Avery, "Pay Attention to Dissimilar-Metal Weld," Nickel Development Institute, 1991. http://www.nipera.org/ /Media/Files/TechnicalLiterature/ GuidelinesforWeldingDissimilarMetals_14018_.pdf

[26] Y. Murakami, "Stress Intensity Factors Handbook,” Pergamon Press, Oxford, 1990, p. 9. 